\title{
Study of Some Sociodemographic Factors in Teenage Pregnancy
}

Kamrun Nessa ${ }^{1 *}$

Mossammat Zebunnesa ${ }^{2}$

Nahla Bari ${ }^{3}$

Adnan Bin Saleh ${ }^{4}$

'Department of Obstetrics and Gynaecology Chittagong Medical College Hospital Chittagong, Bangladesh.

${ }^{2}$ Department of Obstetrics and Gynaecology Upazilla Health Complex, Manikchori Khagrachari, Bangladesh.

${ }^{3}$ Department of Obstetrics and Gynaecology Z H Sikder Women's Medical College \& Hospital Dhaka, Bangladesh.

${ }^{4}$ Department of Orthopedics Chittagong Medical College Hospital Chittagong, Bangladesh.
${ }^{*}$ Correspondence to:

\section{Dr. Kamrun Nessa} Senior Consultant Department of Obstetrics and Gynaecology Chittagong Medical College Hospital Chittagong, Bangladesh. Mobile: +8801819414811

E-mail:dr.kamrun@yahoo.com

\begin{abstract}
Background: Teen age pregnancy is associated with adverse labour outcome. Analysis of teenage pregnancy shown it was related to a range of social back ground, family and individual factors. Objective: To study the socio demographic factors related to teenage pregnancy and its complications. Methods: A cross sectional observational study was performed over a period of one year (September 2009August 2010) at the obstetrics department of Chittagong Medical College Hospital. Consecutive six hundred pregnant mothers admitted for delivery that were fulfilled inclusion criteria included in study group. Among them 300 were teen aged (13$19 \mathrm{yrs}$ ) belongs to group A and 300 were adult (20-29 yrs) belongs to group B. Socio demographic factors like habitation, religion, family income, education, occupation, contraceptive use, pregnancy plan and antenatal care enquired. Labour complications i.e. prolong or obstructed, fetal distress, mode of delivery, stillbirth, birth weight and birth asphyxia was recorded on a preformed questionnaire and statistical analysis done by using SPSS package for windows version 12. Results: Teenage mother has significant lower mean age at delivery than adults $\left(18.61-^{+} 72\right.$ vs. $23.87-^{+} 2.8$ yrs . $\mathrm{P}<.001$ ) among teen mothers $74 \%$ were Muslim, $69 \%$ from rural area and slum. $92 \%$ were house wife $7.3 \%$ service holder and $64.7 \%$ had primary education which almost similar as comparison group. Most of the teen mothers from low income group than adult $(70 \%$ vs.30\%).In group A planned pregnancy were $(18.7 \%$ vs.24.7\%) and contraceptive use ( $21.3 \%$ vs.72\%) which significantly less in comparison to group B. Regular antenatal check up also(10\% vs.26\%, $\mathrm{P}<001)$ less in them. Teen mothers found more anemic (47\% vs. 30\%). Obstructed labour (14.2\% vs. $10.6 \%$ ) Eclampsia( $3.9 \%$ vs. $2.1 \%$ ) and fetal distress (24.2\% vs. $17.1 \%)$ more in A group whereas Prolong labour( $45.5 \%$ vs. $55.3 \%$ ) and Hemorrhage(5.2\% vs. $14.2 \%)$ less in comparison with group B. Caesarean sections and instrumental deliveries significantly higher $(59.3 \%$ vs. $48.7 \%$, ) \& (6\% vs. $2.3 \%)$ and fetal outcome adverse in teen mothers in comparison to adult mothers. Conclusion: Low socioeconomic condition, limited education, religious and cultural factors all appeared to be related with teenage pregnancy and its adverse outcome.
\end{abstract}

Key words: Teen age pregnancy; Socio demographic factors; Cesarean section; Neonatal outcome.

\section{INTRODUCTION}

Teen age is the modern definition of adolescent that means period of life (11-19yrs) during which care free child become responsible adult. In recent years incidence of teen pregnancy increasing due to early onset of puberty, sexual activities in girls and relative lack of education on contraceptive methods ${ }^{1}$. According to BMH \& MMS 2010 teenage constitute $32 \%$ of total population of 160 million in Bangladesh and birth rate 126/1000 live births. Marriage between 15-19yrs are common in Bangladesh i.e. $69 \%$ female married before 20 yrs. Barkat A also states that immaturity of birth canal causes prolonged or obstructed labour ${ }^{2}$. A girl become parent before becoming an adult and both mother and fetus competes for nutrition.

$w w w . c m \circ s h m c j . \circ r g$ 
Usually growth restriction of fetus occur and cannot tolerate stress of labour results fetal distress and to manage this problem incidence of cesarean section/ instrumental delivery increased $^{3}$. Lack of awareness, illiteracy, low socioeconomic condition, delay in seeking ante and intra natal care are the factors adding risk to increased operative interference and perinatal complications in adolescents ${ }^{4}$. In present study evaluation of some socio demographic factors done like socioeconomic condition, level of education, religious and cultural factors, occupation and habitation. Utilization of health care facility like contraception, antenatal care, and clinical condition also analyzed. labour complications, mode of delivery and selected perinatal outcome i.e. stillbirth, low birth weight, birth asphyxia in teen mothers and adult mothers in Chittagong Medical College hospital also observed and compared.

\section{MATERIALS \& METHODS}

A hospital based cross sectional observational study was conducted in Obstetrics department of Chittagong medical college hospital from $1^{\text {st }}$ September 2009 to $30^{\text {th }}$ August 2010. Objective of this study to see socio demographic factors related to teenage pregnancies and complications associated with it and compare with adult pregnancy. Six hundred pregnant mothers admitted in labour ward consecutively included in this study. Among them 300 were teenage (13-19yrs) belongs to group A and 300 were adult (20-29 yrs) in group B.

Inclusion criteria were single tone full term pregnancy (38wks to $42 \mathrm{wks}$ ) with cephalic presentation. All other pregnancies having pre existing illness/GDM/ Parity $>2$ /history of $\mathrm{C} / \mathrm{S}$ were excluded. With informed consent age of the patient calculated in years from guardian's statement and records. Detail about religion, habitation, socioeconomic condition, level of education, occupation, contraceptive history, pregnancy plan, parity and antenatal cheek up were enquired and noted in preformed data sheet. Gestational age calculated from LMP or early USG if available and clinical assessment. Details of delivery events i.e. prolong labour, obstructed labour, eclampsia and fetal distress observed. Mode of delivery i.e. Cesarean section, forceps delivery and ventouse delivery and fetal outcome like stillbirth, low birth weight and birth asphyxia and neonatal death were observed and recorded. Calculated data were compiled, checked and analyzed by using statistical soft ware SPSS version 12 for windows. Result were tested by Chisquare test and unpaired student's ' $\mathrm{t}$ ' test and $\mathrm{P}$ value less than 0.05 considered as statistically significant.

\section{RESULTS}

In figure-1, age of study group were between 16-19yrs with a mean of $18.61 \pm 0.72 \mathrm{SD}$ and in comparison group $23.87 \pm 2.8$ $\mathrm{SD}, \mathrm{P}$ value is $<0.001$ i.e. highly significant.
Table 1 shown socio demographic background of teenage pregnancy. Most of the teen mother was Muslims 74\%, while most of them came from rural area $59.3 \%$, from slum $10 \%$, rest $30.7 \%$ from urban area which had no difference from adult group. Among teenage mother $92.7 \%$ were house wife, $51.3 \%$ of their husband service holder, rest were living abroad, driver, day laborer and doing business.

Regarding education most of the teenage mothers (64.4\%) completed their primary education only $(2.7 \%)$ completed higher secondary level. Husband of teenage completed secondary education about $46 \%$, achieve higher degree only $1.3 \%$, these also like group B. Regarding economic condition teenage mother came from lower class in comparison adult mothers (70\% vs.30\%)

Table 2 shown in group A antenatal checkup less than group B ( $10 \%$ vs. $26.7 \%, \mathrm{P}<0.001$ ) which was highly significant). Regarding contraceptive use in teenage is significantly less than adult mothers $(21.3 \%$ vs. $72 \%, \quad \mathrm{P}<0.001)$ and planned pregnancies in both group $(18.7 \%$ vs. $24.7 \%, \mathrm{P}<.207)$ was insignificant. In group A( $97 \%$ ) were primi para and $(2.7 \%)$ Para two, in B group (84\%) Para 1 and (16\%) Para 2.It was found that most of the teenage mother was significantly anemic (47.3\% vs.30.7\%, P<.003)

Figure 2 - shown vaginal delivery were significantly less in teenage (34.7\% vs.48.7\%, P<.04). Operative delivery were more in them i.e. Cesarean section rate were (59.3\% vs.48.7\%) and instrumental delivery $(6 \%$ vs. $2.6 \%, \mathrm{P}<0.03)$ which was statistically significant.

Complications during labour were mentioned in table 3Obstructed labour more in teenage ie in group A in comparison to group B (14.2\% vs. $10.6 \%$, ) and fetal distress also more in A group $(24.2 \%$ vs. $17.1 \%)$. In contrast hemorrhage and prolong labour more in adult group (5.2\% vs. $14.9 \%)$ and (45.5\% vs. $55.3 \%)$. Genital tract injury occurred only in teenage mother (6.5\%). Eclampsia more in group A (3.9\% vs.2.1\%).

Table IV shown fetal outcome in both groups. In teenage (90\%) baby born alive where as in adult group (95.4\%) baby alive. Stillborn and neonatal death more in teenage (3.3\% vs.1.35\%) and $(6.7 \%$ vs. $3.3 \%, \quad \mathrm{P}<0.049)$ which was statistically significant. Birth asphyxia also more in group A $(20 \%$ vs. $14.1 \%, \mathrm{P}<0.024)$. This observation shown incidence of low birth weight also more $(12.4 \%$ vs. $5.4 \%, \mathrm{P}<0.03)$ in group $\mathrm{A}$.

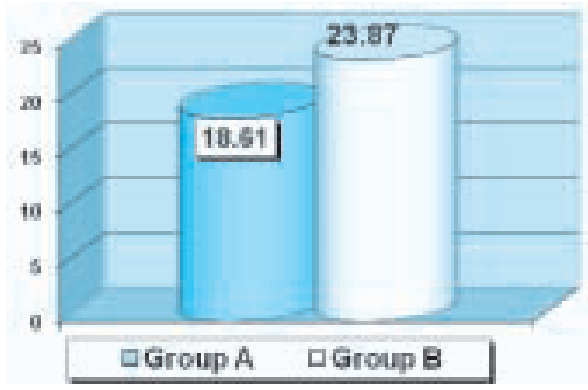

Figure 1 : Bar Chart -: Mean age among the study groups 
Table 1 : Distribution of socio demographic variables among the study groups $(\mathrm{n}=600)$

\begin{tabular}{|c|c|c|c|c|c|c|c|}
\hline \multirow{3}{*}{$\begin{array}{l}\text { OTHER } \\
\text { SOCIAL }\end{array}$} & \multirow[t]{3}{*}{ VARIABLES } & \multicolumn{4}{|c|}{ Study groups } & \multicolumn{2}{|c|}{ Total } \\
\hline & & \multicolumn{2}{|c|}{ Group A } & \multicolumn{2}{|c|}{ Group B } & \multirow[b]{2}{*}{$\mathrm{N}$} & \multirow[b]{2}{*}{$\%$} \\
\hline & & $n$ & $\%$ & $\mathrm{n}$ & $\%$ & & \\
\hline \multicolumn{8}{|l|}{ Mother's } \\
\hline \multirow[t]{2}{*}{ Occupation } & House Wife & 278 & 92.7 & 278 & 92.7 & 456 & 92.7 \\
\hline & Service & 22 & 7.3 & 22 & 7.3 & 44 & 7.3 \\
\hline \multicolumn{8}{|l|}{ Husband's } \\
\hline \multirow[t]{5}{*}{ Occupation } & Service & 154 & 51.3 & 146 & 48.7 & 300 & 50.0 \\
\hline & Business & 56 & 18.7 & 46 & 15.3 & 102 & 17.0 \\
\hline & Living Abroad & 48 & 16.0 & 80 & 26.7 & 128 & 21.4 \\
\hline & Driver & 26 & 8.7 & 18 & 6.0 & 44 & 7.3 \\
\hline & Laborer & 16 & 5.3 & 10 & 3.3 & 26 & 4.3 \\
\hline \multicolumn{8}{|l|}{ Mother's } \\
\hline \multirow[t]{4}{*}{ Education } & Illiterate & 28 & 9.3 & 12 & 4.0 & 40 & 6.7 \\
\hline & Primary Education & 194 & 64.7 & 190 & 63.4 & 384 & 64.0 \\
\hline & Secondary Education & 70 & 23.3 & 94 & 31.3 & 164 & 27.3 \\
\hline & Higher Secondary & 08 & 2.7 & 04 & 1.3 & 12 & 2.0 \\
\hline \multicolumn{8}{|l|}{ Husband's } \\
\hline \multirow[t]{5}{*}{ Education } & Illiterate & 30 & 10.0 & 12 & 4.0 & 42 & 7.0 \\
\hline & Primary Education & 118 & 39.4 & 96 & 32.0 & 214 & 35.7 \\
\hline & Secondary Education & 138 & 46.0 & 182 & 60.7 & 320 & 53.3 \\
\hline & Graduation & 10 & 3.3 & 10 & 3.3 & 20 & 3.3 \\
\hline & Masters & 04 & 1.3 & 00 & 0.0 & 04 & 0.7 \\
\hline \multirow[t]{3}{*}{ Religion } & Muslim & 222 & 74.0 & 214 & 71.4 & 436 & 72.7 \\
\hline & Hindu & 68 & 22.7 & 76 & 25.3 & 144 & 24.0 \\
\hline & Buddhist & 10 & 3.3 & 10 & 3.3 & 20 & 3.3 \\
\hline \multirow[t]{3}{*}{ Habitation } & Rural & 178 & 59.3 & 162 & 54 & 340 & 56.7 \\
\hline & Urban & 92 & 30.7 & 116 & 38.7 & 208 & 34.7 \\
\hline & Slum & 30 & 10 & 22 & 7.3 & 52 & 8.6 \\
\hline \multirow[t]{2}{*}{ Family income } & $<5000$ taka & 210 & 70 & 162 & 54 & 372 & 62 \\
\hline & $>5000$ taka & 90 & 30 & 138 & 46 & 228 & 38 \\
\hline
\end{tabular}

Table 2 : Distribution of use of contraceptive, planned pregnancy and utilization of ANC

\begin{tabular}{|c|c|c|c|c|c|c|c|c|}
\hline \multirow[t]{2}{*}{$\begin{array}{l}\text { Pregnancy } \\
\text { vrelated } \\
\text { ariable }\end{array}$} & & \multicolumn{2}{|c|}{$\begin{array}{l}\text { Study Groups } \\
\text { Group A }\end{array}$} & \multicolumn{2}{|c|}{$\begin{array}{c}\text { Total } \\
\text { Group B }\end{array}$} & \multirow[t]{2}{*}{ Sig. } & \multirow[b]{2}{*}{$\%$} & \\
\hline & & $\mathrm{n}$ & $\%$ & $\mathrm{n}$ & $\%$ & & & \\
\hline $\begin{array}{l}\text { Ante natal } \\
\text { Check up }\end{array}$ & $\begin{array}{l}\text { Regular } \\
\text { Infrequent } \\
\text { None }\end{array}$ & $\begin{array}{l}30 \\
216 \\
54\end{array}$ & $\begin{array}{l}10 \\
72 \\
18\end{array}$ & $\begin{array}{l}80 \\
174 \\
46\end{array}$ & $\begin{array}{l}26.7 \\
58 \\
15.33\end{array}$ & $\begin{array}{l}90 \\
390 \\
120\end{array}$ & $\begin{array}{l}15 \\
65 \\
20\end{array}$ & $\begin{array}{l}\mathrm{P}=0.036 \\
\mathrm{~S}\end{array}$ \\
\hline $\begin{array}{l}\text { Status of } \\
\text { pregnancy }\end{array}$ & $\begin{array}{l}\text { Planned } \\
\text { Unplanned }\end{array}$ & $\begin{array}{l}56 \\
244\end{array}$ & $\begin{array}{l}18.7 \\
81.3\end{array}$ & $\begin{array}{l}74 \\
226\end{array}$ & $\begin{array}{l}24.7 \\
75.3\end{array}$ & $\begin{array}{l}130 \\
470\end{array}$ & $\begin{array}{l}21.7 \\
78.3\end{array}$ & $\begin{array}{l}\mathrm{P}=0.207 \\
\mathrm{NS}\end{array}$ \\
\hline $\begin{array}{l}\text { Contraceptive } \\
\text { history }\end{array}$ & $\begin{array}{l}\text { Used } \\
\text { Not Used }\end{array}$ & $\begin{array}{l}64 \\
236\end{array}$ & $\begin{array}{l}21.3 \\
78.7\end{array}$ & $\begin{array}{l}84 \\
216\end{array}$ & $\begin{array}{l}28 \\
72\end{array}$ & $\begin{array}{l}148 \\
452\end{array}$ & $\begin{array}{l}31.3 \\
68.7\end{array}$ & $\begin{array}{l}\mathrm{P}=0.213 \\
\mathrm{NS}\end{array}$ \\
\hline Parity & $\begin{array}{l}\text { Para-1 } \\
\text { Para-2 }\end{array}$ & $\begin{array}{l}292 \\
8\end{array}$ & $\begin{array}{l}97.3 \\
2.7\end{array}$ & $\begin{array}{l}252 \\
48\end{array}$ & $\begin{array}{l}84 \\
16\end{array}$ & $\begin{array}{c}544 \\
56\end{array}$ & $\begin{array}{l}90.7 \\
9.3\end{array}$ & $\begin{array}{l}\mathrm{P}<0.001 \\
\mathrm{HS}\end{array}$ \\
\hline Anemia & $\begin{array}{l}\text { Present } \\
\text { Absent }\end{array}$ & $\begin{array}{l}142 \\
158\end{array}$ & $\begin{array}{l}47.3 \\
52.7\end{array}$ & $\begin{array}{l}92 \\
208\end{array}$ & $\begin{array}{l}30.7 \\
69.3\end{array}$ & $\begin{array}{l}234 \\
366\end{array}$ & $\begin{array}{l}39 \\
61\end{array}$ & $\begin{array}{l}\mathrm{P}<.003 \\
\mathrm{HS}\end{array}$ \\
\hline
\end{tabular}

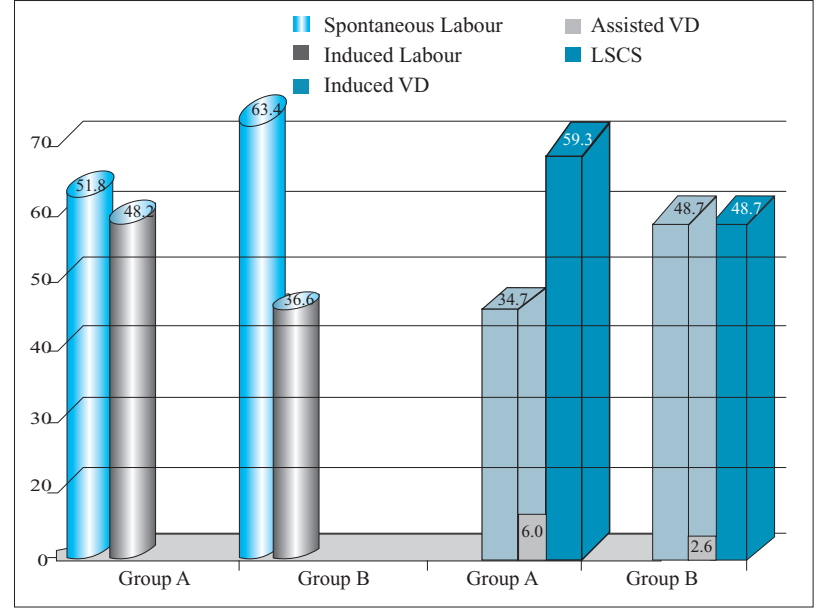

Figure 2 : Bar Chart- Distribution of initiation of labour and mode of delivery among the study group

Table 3 : Distribution of complications during labour among the study group $(\mathrm{n}=248)$

\begin{tabular}{llllllll} 
Complications & \multicolumn{3}{c}{ Study groups } & \multicolumn{3}{c}{ Total } \\
during labour & Group A & \multicolumn{3}{c}{ Group B } & & \\
& $\mathrm{N}$ & $\%$ & $\mathrm{~N}$ & $\%$ & $\mathrm{~N}$ & $\%$ \\
\hline Prolonged labour & 70 & 45.4 & 52 & 55.3 & 122 & 49.2 \\
Obstructed labour & 22 & 14.3 & 10 & 10.6 & 32 & 12.9 \\
Fetal distress & 38 & 24.7 & 8 & 17.0 & 46 & 21.8 \\
Hemorrhage & 8 & 5.2 & 14 & 14.9 & 22 & 8.9 \\
Genital tract injury & 10 & 6.5 & 00 & 0.0 & 10 & 4.0 \\
Eclampsia & 6 & 3.9 & 2 & 2.1 & 8 & 3.2 \\
Total & 154 & 100.0 & 94 & 100.0 & 248 & 100.0
\end{tabular}

Table 4 : Distribution of foetal outcomes among the study group (With $\mathrm{X}^{2}$ test significance)

\begin{tabular}{lccllllll} 
Fetal & & Group A & \multicolumn{2}{c}{ Group B } & Total & & SIG \\
outcome & & $\mathrm{N}$ & $\%$ & $\mathrm{n}$ & $\%$ & $\mathrm{~N}$ & $\%$ & \\
Baby alive & & 270 & 90.0 & 286 & 95.4 & 556 & 92.7 & \\
Still born & & 10 & 3.3 & 04 & 1.3 & 14 & 2.3 & $\mathrm{P}=0.049$ \\
Neonatal death & & 20 & 6.7 & 10 & 3.3 & 30 & 5.0 & Significant \\
Total & & 300 & 100.0 & 300 & 100.0 & 600 & 100.0 & \\
Birth asphyxia & Present & 58 & 20.0 & 44 & 14.9 & 102 & 17.4 & $\mathrm{P}=0.024$ \\
(n==586) & Absent & 232 & 80.0 & 252 & 85.1 & 484 & 82.6 & Significant \\
Birth Weight & $<2.5 \mathrm{~kg}$ & 36 & 12.4 & 16 & 5.4 & 52 & 8.8 & Significant \\
& $\Rightarrow 2.5 \mathrm{~kg}$ & 254 & 87.6 & 280 & 94.6 & 534 & 91.2 & $\mathrm{P}=<.03$ \\
& & & & & & & & \\
\hline
\end{tabular}

\section{DISCUSSION}

Present study demonstrates that the increased risks for poor pregnancy outcomes associated with low maternal age substantially result from teenagers' poor socioeconomic situation. Current study shown mean age of the teenage 18.61 year which is the tradition of Bangladesh where $69 \%$ marriage during teenage were resulting higher proportion of teenage pregnancies $^{2}$. 
low socio economic status, limited education .religious and cultural factors all appeared to be related with teen age pregnancy ${ }^{5-8}$. Being socially discriminated against and economically poor, young women become victims of gender bias tend to have little decision making power. The likelihood of teenage pregnancy and childbearing seemed to be associated with low level of education ${ }^{8}$. Education could play a significant role in developing self confidence, increasing age at first sexual intercourse and delaying marriage ${ }^{9}$. In present study shown that teenage mothers likely to have completed secondary school (23\% vs. $31.3 \%$ ) compared to adult group. More over compulsory sex education can help to empower the girls, which is the most effective strategy to prepare them for late marriage, planned and delayed pregnancy and better motherhood. ${ }^{10}$

The present study shown $59.3 \%$ of teenage mothers resides in rural area $10 \%$ from slum and $30.7 \%$ from urban and comparison group almost same like 54\% from rural and 7.3\% from slum. So there is no difference in residence in both groups which corresponds with observation by Abul Barkat ${ }^{2}$. In current study $74 \%$ teen age mother came from Muslim family, $22.7 \%$ from Hindu, 3.3\% from Buddhist. Mustafa Kamal shown that Muslim women likely to have childbearing earlier than non Muslims. The cultural tradition of Muslims lead to have early birth and, also may because of that these country resident mainly muslims ${ }^{11}$. This study also shown $92 \%$ of mothers teenage were house wife only $7.3 \%$ service holder almost same in comparison group. Employment can improve confidence and able for decision making about delaying early marriage and child bearing. Husband's occupation also plays an important role. Husbands who were living abroad, illiterate or less educated wants child earlier without considering early age of wife. In present study most of the husband of mothers teenage were completed their education up to secondary. Only few were graduate $(3.3 \%)$ or master's degree holder $(1.3 \%)$.

Regarding economic condition $70 \%$ adolescent came from poor family where as in adult mother $54 \%$ from poor economic condition. Shrestha demonstrated incidence of teenage pregnancy is significantly higher in the lower social classes $(52 \%)$ than higher social class $(26 \%)^{12}$. Structural and social inequalities, poverty and low level of education all made young people vulnerable to pregnancy in early age ${ }^{13}$. In present study most of teenage pregnancies were unplanned in comparison with group B $(81.3 \%$ vs. $75.3 \%)$. Regarding contraceptive teenage mother used less in comparison to group B $(21.3 \%$ vs. $72 \%, \mathrm{P}<.001)$ which statistically significant. WHO discussion paper 2003 shown one survey in Kenya revealed 89\% of teenaged never used contraceptive and Uganda used only $18 \%$. According to BDHS $15.3 \%$ teenaged not use any contraceptive method this are almost similar with current study ${ }^{14}$. Illiteracy, lack of awareness and counseling about contraception and fear about future fertility are main factors for lower contraceptive prevalence in teenage. Delay in marriage, therefore consequent delay in pregnancy would give opportunity for higher education, increasing chance of empowerment and planned pregnancy.
Current study shown only $10 \%$ adolescent mother receive regular antenatal care and adult group 26.7\%. Nahathi W et al. reported adolescent mother had antenatal care less than four times than adult $(13.4 \% \text { vs. } 25.9 \%)^{15}$. In developing countries antenatal care often unsatisfactory but care of teen mother falls short even of national standard (48\%) is insufficient. Socioeconomic deprivation remains significantly important, reflecting differential access to health service among teenage mothers ${ }^{16}$. In this study significant number were primipara $97.3 \%$, para two only $2.7 \%$ whereas in adult group $16 \%$ para two. It was may be due to age limit of adolescent, they have less time to be pregnant for second time. It was found that most of the adolescent mother was significantly anemic (47.3\% vs. $30.7 \%, \mathrm{P}<.003)$.A north India study has shown the prevalence of anemia is high(46\%) among teenage mothers, which occurs due to low intake of dietary iron this result similar to current study ${ }^{16}$.

Teenage mothers had (33.7 \% vs.48.7\%) less spontaneous vaginal deliveries (SVD) in comparison with group B and higher $(6 \%$ vs. $2.6 \%)$ instrumental delivery and cesarean section $(59.3 \%$ vs. $48.7 \%)$ in group A. So there were significantly $(\mathrm{P}<.03)$ higher operative delivery in teen mothers. In one study done by Amber T et.al C S was the major route of delivery in teenage $(43.6 \%$ vs. $10.6 \%, \mathrm{P}<0.001)$ and SVD was lower $(60 \%$ vs. $85 \%, \mathrm{P}<0.001) .{ }^{1}$ Another study done in BSMMU shown $44 \%$ had CS which was higher in adolescent mother ${ }^{17}$. In one study done in Rajavithi hospital in Bangkok shown prevalence of $\mathrm{CS}$ is significantly higher and major route than adult(18.7 vs. $13.3 \%, \mathrm{P}<0.006)$ teenage ${ }^{18}$. Present study matches with these studies. Regarding complications during labour in current study obstructed labour and fetal distress were more in group A in comparison with group B $(14.3 \%$ vs. $10.6 \%)$ and $(24.7 \%$ vs. $17 \%)$ which was matched with one study in which they shown cephalic pelvic disproportion, Prolong labour higher in adolescent mothers ${ }^{19}$. In contrast incidence of hemorrhage $(5.2 \%$ vs. $14.9 \%)$ and prolonged labour (45.5\% vs. $55.3 \%)$ were higher in adult group. Eclampsia also more in teen age (3.9\% vs. $2.1 \%$ ) in comparison to adult mother.

In present study $88 \%$ baby bore alive, stillbirth, rate $53.3 \%$ vs. $33 \%$ and death within 7 days of birth $6.7 \%$ vs. $3.9 \%$. So total perinatal death was $(12 \%$ vs.6.6\%.P $<0.049)$ significantly higher in teenage similar result shown in some studies in south Asia and Jordan ${ }^{20-21}$. Kumar A et al. shown group A associated with high fetal and neonatal mortality $(1.9 \%$ vs. $.3 \%, 3.8 \%$ vs. $.5 \%$, $\mathrm{P}<.05)$ respectively ${ }^{22}$. Birth asphyxia in group A significantly higher $(20 \%$ vs. $14.91 \%$.P $<0.024)$ in present study. Higher incidence of birth asphyxia and low Apgar score shown in some studies ${ }^{23}$. In current study birth weight of the baby of group A significantly less $(2.78$ vs.2.88, $\mathrm{P}<.01)$ in comparison with adult group. Incidence of low birth weight also significantly more $(12.4 \%$ vs.5.4\%, $\mathrm{P}<.03)$ in teenage. Sariar B et al. described that incidence of low birth weight in Bangladesh is $30 \%$, In Pakistan is $9.9 \%{ }^{24}$. This finding matched with current study. 
Judith B et al. find in her study at Philippine birth weight of the baby of adolescent mothers were less than adult groups (2.7 vs.2.8, $\mathrm{P}<0.01$ ) which was completely matched with this study and in some other studies also shown same result ${ }^{25-27}$. Low birth weight babies have increased risk of perinatal mortality and morbidity. Proper antenatal care and balanced nutritional supplement improved mean birth weight ${ }^{28}$.

\section{LIMITATIONS OF THE STUDY}

The sample size was small and as this study was single hospital based, national picture may not be properly reflected.

\section{CONCLUSION}

Teenage from socially disadvantaged background characterized by poverty, welfare dependence, academic under-achievement and low parental educational aspirations are at an increased risk of becoming pregnant at an early age. So, teenage pregnancy should be addressed as high risk and factors responsible for this must be removed. In particular, future research with longitudinal studies in Bangladesh is needed to explore changes over time.

\section{DISCLOSURE}

All the authors declared no competing interest.

\section{REFERENCES}

1. Tufail A, Halima A, Hasmi. Maternal and Perinatal outcome in teenage pregnancy in a community based hospital. Pakistan journal of Surgery. 2008; 24(2):130-134

2. Bark at $\mathrm{A}$, Adolescent and youth reproductive health in Bangladesh. 2003;1-10.

3. Bari W, Chowdhury RT, Islam MA, Chacraborti N, Akhter H A H. The determinants of perinatal mortality in rural Bangladesh. European J of Contra \&Repro H C. 2002;7(48):216-222.

4. Paranjothy S, Broughton H, Adappa R, Fone D.Teenage pregnancy: who suffers? Arch Dis Child. 2009;94:239-245.

5. Brenon L, McDonanald J, Shlomowitz R. Teenage births and final adult height of mothers in India.Journal of Biosocial science. 2005;37:185-191

6. Sharma A,Vema K, Katri S,Kannan A. Determinants of pregnancy in adolescents in Nepal.Indian Journal of Pediatrics. 2002;69: 19-22

7. Khandait D,Ambedkar N, Zodpey S,Vasudeo N. Maternal age as a risk factor for stillbirth. Indian journal of Public health.2000; 44:28-30.

8. Goonewardena I, Deeyagaha Waduge R. Adverse effects of teenage pregnancy. Cylon Medical Journal.2005; 50:116-120.

9. Waszak C, Thapa S, Davey J. Influence of gender norms on the reproductive health of adolescent in Nepal-perspective of youth. World Health Organization, Geneva.2003; link -http://www.who.int/reproductive.

10. Acharya D R, Bhattari R, Poobalan A.Factor associated with teenage pregnancy in south Asia. Health Science J. 2010;4(1)1:3-6.

11. S.M.Mostafa kamal. Adolescent motherhood in Bangladesh. XXVI, IUSSP International Population conference Morocco. 2009; 49.

12. Shrestha S. Socio-cultural factors influencing adolescent pregnancy in rural Nepal. International Journal of adolescent Medicine \& health.2002;14:101-109.

13. Rashid S. Emerging changes in reproductive behavior among married adolescent girls in an urban slum in Dhaka, Bangladesh. Reproductive health matters.2006;14:151-159.

14. Prosannajid S. Determinants of adolescent fertility behavior in Bangladesh. Soc Sci. 2009; 4(6):680-684.

15. Nahathai W, Pitcha P, Somkid P. Incidence \&complications of teenage pregnancy at Chonburi hospital. J Med Assoc Thai. 2006; 89(4):118-123.

16. Pathok P, Singh P, Kapil U, Raghuvanshi R. Prevalence of iron, vitamin A and iodine deficiencies among adolescent pregnant mothers. Indian journal of Pediatrics. 2003; 70: 299-301.

17. Sultana N, Begum S, Parveen T, Haque S R, Ahmed S. Teenage pregnancy and its outcome in Bangladesh; Has the situation improved? BJOG. 2004; 19(4):123.

18. Ekachai K, Supanan C, Kasoran T, Suvanna A, Uriwan C. Outcome of teenage pregnancy in Rajavithi Hospital,Bangkok.J Med Assoc Thai. 2010;93(1):1-8.

19. Province N, Suradet B, Chiraphorn M, Ngamboon R .Epidemiology and outcome of teenage pregnancy Wingsha district. Med Asso Thai. 2008; 84(6):21-26.

20. Acharya D R, Bhattari R, Poobalan A.Factor associated with teenage pregnancy in south Asia. Health Science J. 2010; 4(1)1:3-6.

21. S Ziadeh.Obstetrics outcome of adolescent pregnancies in North Jordan. Arch Gynaecol obstet. 2001; 265:26-29.

22. Kumar A,Singh T, Basu S, N Pandy S, V Bhargava .Outcome of teenage pregnancy. Ind J of Paed. 2007;74(10):927.

23. Konje JC, Palmer A, Watson A ,Hay DM, Imrie A, Ewing P. Early teenage pregnancies in Hull.Br J obst Gynaecol. 2002; 99(12):969-973.

24. Sareer B, Linda M, Keneth M, Payne R, lisboa P.Risk factor for low birth weight in the public hospital at Peshawar, NWFPPakistan . BMC public Health. 2008;8:197.

25. Judith BB, Linda SA. Assessing the net effect of young maternal age on birth weight. Am J Hum Biol. 2003; 15:733-740.

26. Aysun O, Mehmet Z, Barsen G. Adolescent pregnancy in west turkey. Med Assoc Saudi. 2006; 27(8):1177-1182.

27. PC Chandra, H.J Scheavello, B Ravi, AG Weinstein, FB hook. Pregnancy outcome in urban teenagers. Int J of Gynae \& Obst. 2009; 79:117-122.

28. J M. Wallace, J S. Luther, J S Milne, R P Aitkin. Nutritional Modulation of adolescent pregnancy outcome-A review.doi;10.1016/jplacenta.2005.12.002. 